\title{
Unweaving the Shroud of Mourning: Don DeLillo's The Body Artist
}

Yas Kefenini Sökmek: Don DeLillo'nun The Body Artist Adlı Romanı ${ }^{1}$

\author{
Selen Aktari-Sevgi \\ Başkent University, Turkey
}

\begin{abstract}
Don DeLillo's The Body Artist (2001) presents Lauren Hartke's (36), a body artist, work of mourning in the form of a stage performance called "Body Time". The experimental narrative of the body performance reflects the collapse of the boundaries between subject and object, internal and external, body and mind, time and space, and memory and art. Lauren cannot overcome the shock over her husband's, Rey Robles (64), loss because he tragically commits suicide. After her husband's death, she discovers an uncanny stranger, Mr. Tuttle, in her house, who mechanically repeats words in a nonsensical context, dissolves the boundaries between space and time through confusing grammatical tenses, and reanimates the conversations between Lauren and Rey by mimicking their voices. Signifying simultaneously an external and an internal other, Mr. Tuttle exhibits Lauren's subjectivity-in-crisis. When Lauren's work of mourning is analysed by using Jean Laplanche's psychoanalytical theories, it is observed that Lauren is not detaching herself from her lost other, as is in Freudian definition of the work of mourning, by healing herself through art. On the contrary, she detaches herself from her lost other to re-attach herself to the other in order to construct a new form of subjectivity. Laplanche discusses this process by drawing an analogy between mourning and Penelope's weaving/unweaving a shroud for her father-in-law, Laertes. For him, Penelope is weaving/unweaving this shroud to mourn Ulysses, not Laertes. By identifying a similar relation between Lauren's mourning and her body art, this article argues that what renders Lauren's mourning traumatic is the feeling of guilt she represses in the face of loss. Through the use of Laplanche's theoretical concepts such as "enigmatic message," "afterwardsness," and "weaving/unweaving," this article further discusses how Lauren's body art unweaves her childhood trauma, her mother's early death, to weave her subjectivity in relation to her dead others.
\end{abstract}

Keywords: Don DeLillo, Jean Laplanche, mourning, The Body Artist, trauma

Öz

Don DeLillo'nun The Body Artist (2001) başlıklı romanı, bir beden sanatçısı olan Lauren Hartke'nin (36) yas sürecini, "Beden Zamanı" adlı bir sahne performansı biçiminde sunar. Bu beden performansının deneysel anlatımı özne ve nesne, içsel ve dışsal, beden ve zihin, zaman ve mekan, bellek ve sanat arasındaki sınırların yıkılışını yansitır. Lauren, eşi Rey Robles'un (64), kaybının şokunu atlatamaz çünkü Rey trajik bir şekilde intihar etmiştir. Eşinin ölümünden sonra Lauren evinde, Mr. Tuttle adında, anlamsız bir bağlam içinde ve mekanik bir şekilde kelimeleri tekrar eden, fiillerin

${ }^{1}$ An earlier version of this article was presented at the $16^{\text {th }}$ International Cultural Studies Symposium: Narratives of Trauma, Ege University, Izmir, Turkey, May 10-12, 2017.

CUJHSS, June 2021; 15/1: 163-174.

(C) Çankaya University ISSN 1309-6761 Printed in Ankara

Submitted: Jan 4, 2021; Accepted: May 29, 2021

ORCID\#: 0000-0002-1729-4194; saktari@baskent.edu.tr 
zamanlarını karıştırarak konuşup mekan ve zaman arasındaki sınırları yok eden, Lauren ve Rey'in seslerini taklit ederek aralarında geçen diyalogları yeniden canlandıran tekinsiz bir yabancıyla karşılaşır. Aynı anda hem içsel hem de dışsal ötekiyi simgeleyen Mr. Tuttle, Lauren'ın öznellik krizini sergiler. Lauren'ın yas süreci Jean Laplanche'ın psikanalitik kuramları ışığında incelendiğinde, Lauren'ın kaybettiği ötekine olan bağlarını, Freud'un yas süreci tanımında olduğu gibi, sanat yoluyla kendini iyileștirerek koparmadığı gözlemlenir. Aksine, kaybettiği ötekinden kendini, ona yeniden bağlanarak yeni bir öznellik kurmak için koparır. Laplanche bu süreci yas tutmak ve Penelope'nin kayınpederi Laertes için dokuduğu kefenin ilmeklerini örmesi ve çözmesi arasında bir benzerlik kurarak tartışır. Laplanche'a göre Penelope, Laertes'in değil, Ulysses'in yasını tutmak için bu kefeni örmekte ve sonrasında sökmektedir. Bu makale Lauren'ın yas sürecini travmatik hale getirenin, kayıp karşısında duyduğu suçluluğu bastırmak olduğunu iddia eder. Bu bakış açısına ek olarak, Laplanche'ın "bilmecemsi mesaj," “sonradan etki" ve “örme/sökme” gibi kuramsal terimlerini kullanarak, bu makale, Lauren'ın beden sanatının, kaybettiği öznelliğini ötekiler üzerinden yeniden kurabilmek için çocukluk travmasını annesinin erken ölümünü - nasıl çözdügünü tartışır.

Anahtar Kelimeler: Don DeLillo, Jean Laplanche, yas, The Body Artist, travma

Don DeLillo's The Body Artist (2001) is a narrative of working through traumatic loss. The protagonist Lauren Hartke's traumatic experience of her husband's, Rey Robles, tragic suicide turns into a body art performance that reflects Lauren's loss of subjectivity entailing the loss of language, memory, spatiality and temporality. Lauren is a 36-year-old successful body artist, who "is acting, always in the process of becoming another or exploring some root identity" (DeLillo 111) ${ }^{2}$ and Rey is a 64-year-old awarded film director whose decline in his professional life is attributed to "alcoholism and intermittent depression" (TBA 27). Lauren's performative process of bereavement during the course of the novel and its simultaneous representation as body art are conveyed to the reader through two framing passages: Rey's obituary and Lauren's close friend Mariella Chapman's review of Lauren's performance on stage in Boston. Rey's obituary presents the cause of Rey's death, which is "a self-inflicted gunshot wound" (TBA 25) taken place in his first wife's apartment. On the other hand, the review on Lauren's choreography reveals that the mourning process depicted in the novel, which involves Lauren's discovery of an uncanny figure in her house and her experiences with him, is also a preparation for her upcoming body performance. This performative mourning is a reflection of Lauren's trauma that depicts her confrontation with alterity.

According to Freud, the unbearable pain felt through the work of mourning is a mystery. Jean Laplanche, in his critical reading of Freud's metapsychology, Essays on Otherness (1999), highlights that Freud does not provide a reason why it becomes so. He quotes Freud's remarks on mourning as follows:

\footnotetext{
${ }^{2}$ Hereafter cited as TBA.
} 
But why it is that this detachment (Ablösung) of libido from its objects should be such a painful process is a mystery to us, and we have not hitherto been able to frame any hypothesis to account for it. We only see that libido clings to its objects and will not renounce those that are lost even when a substitute lies ready to hand. Such then is mourning. (Freud 307; Laplanche, Otherness 254)

For Laplanche, this is a very "abrupt" and even "impatient" conclusion for a definition of mourning. ${ }^{3} \mathrm{He}$ criticizes this definition by questioning the subject's resistance to give away the lost object when there is already a substitute to cling to. He asks: "Why not change the object, as soon as the old one has gone [?] [...] Why is all this work required to change object? Why so much palaver?" Thus, emphasizing that it is necessary to "re-open the question of morning in its entirety," Laplanche offers a "route that is both poetic and linguistic" (Otherness 254). Very much like Freud does, he also uses Greek myths to present his critique of Freudian metapsychology. He refers to Homer's Penelope's weaving and unweaving not only in relation to mourning but also to describe how psychoanalysis works. Analysing Lauren's performative process of mourning through art in relation to Penelope's in the light of Laplanche's reformulation of mourning reveals that the mourning subject does not have to detach itself from the lost object in order to end the bout of pain.

Laplanche claims that Freud discards an important aspect of the mourning process that works through the function of the other. According to him, mourning is not a subjective process in which the subject finally constructs its subjectivity by demarcating its borders between itself and the mourned other. On the contrary, for the subject-in-crisis after the death of the other, it is necessary to embrace the other in order to form its subjectivity anew which is already always decentred. In order to explain the role of the other, Laplanche gives the example of Penelope's work of mourning for her husband, Ulysses, who may never return, and draws attention to the generally accepted but, in his view, problematic interpretation of "her weaving with the sole aim of unweaving" her father-in-law's, Laertes, shroud to get rid of her suitors until her husband returns. By examining the Greek word, "analuein" used by Homer, which means not only "to unweave, to undo, to untie" but also "to analyze," Laplanche offers an analogy between analysing and undoing the knots that leads him to read Penelope's work in a reverse way. Penelope does not weave to unweave so that her shroud will never finish. He says, "Perhaps she only unweaves in order to weave, to be able to weave a new tapestry. It would thus be a case of mourning, mourning for Ulysses. But Penelope does not cut the threads, as in the Freudian theory of mourning; she patiently unpicks them, to be able to compose them again in a different way" (Otherness 256). Laplanche

\footnotetext{
${ }^{3}$ In "On Transience," Freud is perplexed by the pain felt for the lost object in the mourning process because libido, inclined to avoid pain, should replace the lost object with the new one in the economic model of psychoanalysis. He discusses impossible mourning later as a pathological case of melancholy in "Mourning and Melancholia" (1917).
} 
claims that since Freud cannot see mourning "as a work of unweaving," it becomes "a prototype of melancholy" (Otherness 257). However, although Penelope never cuts off her ties with her husband, she is not suffering from melancholia. She unties the knots that have been already woven with the aim of composing them again, but in a different way, by the formation of new knots. She detaches herself from the lost other in order to attach herself again and construct a new subjectivity in relation to the other. When Penelope forms a new subjectivity in relation to the other through her work of mourning, she will stop unweaving.

Laplanche states that, according to Freud, the threads that are unwoven in the work of disentangling of the libido from the object are the "memories" and "expectations" that attach the subject to the other. He quotes from "Mourning and Melancholia": "Each single one of the memories and expectations in which the libido is bound to the object is brought up and hyper-cathected, and the detachment of the libido is accomplished in respect of it" (Freud 245; Laplanche, Otherness 257). In Laplanche's opinion, Freud, however, disregards "the context of these memories and expectations" which is, in fact, formed by the other because the "context" is the place that preserves the message of the other which is unknown to us. "For the person in mourning, that message has never been adequately understood, never listened to enough. Mourning is hardly ever without the question: what would he be saying now? What would he have said? Hardly ever without regret or remorse for not having been able to speak with the other enough, for not having heard what he had to say" (Otherness 258). Therefore, what remains unsolved behind after the loss is the enigmatic message of the other. This is what Laplanche means by the otherness of the other. This otherness refers to the other's unconscious, which is itself an otherness to the other itself.

Within the framework of this discussion, The Body Artist also provides its readers with a representation of Penelope's mourning process. Like Penelope, Lauren also continuously unweaves and then weaves her ties to her husband through her body's repetitive actions and repetitive utterances. That is, she weaves her bonds to him by clinging onto him through reliving her memories with him, and then she unweaves these bonds, and within a Laplanchean perspective, she analyses and decodes these memories in order to weave a new tapestry, a new self. This repetitive work, which represents the work of mourning, requires time, but it will end somehow. As Laplanche states, "One can imagine that one evening the new cloth, for a while at least, will not be unwoven" (Otherness 256). Thus, Lauren's mourning for her husband also ends when she cures her trauma reflected by her repetitive actions and repetitive conversations with the imagined other by the means of her body art performance called "Body Time". In other words, Lauren cures herself of her trauma when she "force[s] her trauma into representation" (Di Prete 484) and constructs her subjectivity anew on the enigmatic message of the other.

The novel starts with the narration of the last morning Lauren has spent with Rey which turns out to be a memory repetitively replaying on the screen of 
Lauren's mind throughout the novel. Lauren reenacts this last moment she spent with her husband in her mind's eye because their everyday ritual of having breakfast turns into a traumatic scene after Rey commits suicide. The conversation they have during the breakfast over the nick Lauren sees on Rey's face reveals that Rey has already planned to commit suicide on that day because when Lauren advises him not to shave as soon as he wakes up; Rey answers, "I want God to see my face" (TBA 11). However, Lauren cannot understand the importance of this ironical remark at that moment. Lauren's reliving this scene again and again indicates that Lauren is unweaving, that is "analysing," the final memories she has had with Rey. She is trying to confront the enigmatic message of the other that she could not understand before. Then, Lauren remembers the rest of this scene based on a conversation about an uncanny noise she frequently hears in the house and wants to learn whether Rey hears it too. Rey asserts that he has not heard it lately; the noise is gone, but when Lauren insists that she still hears it, he says: "Good, I'm glad. You need the company" (TBA 16). This is another ironical remark Rey makes implying that Lauren needs company when he is dead. And when Rey implants his absence into Lauren by his suicide, this noise attains a ghostly form, and starts to accompany Lauren during her mourning process.

Another uncanny incident that takes place during the breakfast in their final morning is Lauren's picking a hair out of her mouth which belongs to neither her nor Rey and her wondering about how a hair from someone else's head has reached her mouth. Rey implies humorously the possibility of Lauren's carrying the hair since her childhood. Rey's reference to Lauren's childhood by the image of a stranger's hair also indicates the erasure of the demarcation between the subject and the object due to "the intimate passage of the hair from person to person" (TBA 9). Lauren also relives this incident several times in her mind during her mourning process because it is also symbolically related to her childhood trauma, the loss of her mother, which can be addressed only after she finishes her work of mourning because this "early trauma [is] not completely worked through and [implies] the possibility of transgenerationally transmitted secrets, conflicts, and traumas within the mother" (Di Prete 489). In Laplanchean terms, the hair represents the otherness (the unconscious) of Lauren's m/other.

In the first days after Rey dies, Lauren performs a liminal subjectivity attended with disruption of temporality and spatiality. Everything for her is "slow and hazy and drained [...] days moved so slow they ached" (TBA 29-30). She feels that her body is "[s]lightly foreign and unfamiliar" (TBA 31). Eugenie Brinkema states that "[g]rief is derived from grever (afflict, burden, oppress), from the Latin gravare (to cause grief, make heavy) - hence, the etymological intimacy of grief and gravity, both from gravis (weighty)". This argument indicates that grief has a gravity and "the effect of [its] force as a pull into the stasis of the pose, this weighting on the corpus in bent tense limbs and joints, involves a formal orientation of posture toward the grave" (109). This effect of grief can be observed throughout the novel in Lauren's repetitive movements in slow motion and in frozen time. Her feeling like she is sinking in the ground and 
forgetting how to stand is an image which shows an orientation toward the grave. Her unbearable pain due to her loss is also seen in the following expressions: She "want [s] to disappear in Rey's smoke, be dead, be him" (TBA 32) and she wakes early every morning to "the first murderous instant of lying in bed" (TBA 35) without Rey. However hard she tries to make plans "to organize time until she could live again [...] the world was lost inside of her" (TBA 36).

One day she suddenly hears the unidentified noise she has heard when Rey was alive. When she follows it, she finds an uncanny figure in one of the bedrooms of the house and she later names him after a science teacher in her high school, Mr. Tuttle. The novel is basically founded upon Lauren's experiences with Mr. Tuttle that take place "in a perennial present that is both past and future at the same time" (Kontoulis and Kitis 223) and this distorted temporal structure causes the collapse of the conventional language as is observed in the quotation below:

"Then when it comes to me."

"What?"

"A thing of the most. Days yes years."

"Do you know what that means? A day. A year. Or did you hear me use these words?"

"Say some words."

"Say some words."

"In when it comes."

"In when it comes. What?" she said.

"Leave into leaving."

"Who is leaving?"

"This is when you, yes, you said."

"What did I say?" [...] He talked in his own voice, which was reedy and thin and trapped in tenses and inflections, in singsong conjugations."

(TBA 86, 66)

The novel presents several conversations between Lauren and Mr. Tuttle similar to the one quoted above, which can be analysed within the framework of Laplanche's definition of the mourning subject's dependence upon the enigmatic message of the dead other. As Laplanche says: "the enigma of mourning takes us to the function of the enigma in mourning: what does the dead person want? What does he want of me? What did he want to say to me?" (Otherness 259). These enigmatic messages of Mr. Tuttle (otherness of the other), directed at Lauren (subject-in-crisis), destabilize Lauren's life while she is trying to hold onto her daily routines and create gaps in her reality which intensifies her sense of loss and melancholy (Hinton 641). She cannot understand what Mr. Tuttle, who is also representing the return of the other, says or does.

According to Ladson Hinton, enigmatic experience destabilizes and provokes the development of the ego that seeks to stabilize these messages. However, it is the unsayability of those things which form these gaps in the subject's 
reality. Since the other is dead, these messages will remain enigmatic forever. No matter how Lauren may ponder upon the last words her husband uttered and try to know the reasons that have led him to commit suicide, she will never be able to get an answer. Her talk with Isabel Corrales, Rey's first wife, on the phone after the funeral presents an additional perspective on Rey's personality, but it still does not provide a substantial explanation for his suicide. Isabel admits that she had been expecting a suicide attempt from him. "We all knew this about him. For years he was going to do this thing. It was a thing he carried with him. It was his way out. He wasn't a man in despair. This thing was a plan in his mind. [...] This man hated who he was" (TBA 61-2). For Isabel, it is not a depression, but self-hatred that has killed Rey. Lauren does not want to listen to Isabel anymore because she cannot process Rey's death yet. She is in a liminal state in which time and place, therefore, cause and effect relationship does not function anymore. She immediately retreats into her "bubble world" (TBA 50) with Mr. Tuttle. Within this world, she is not forced to confront Rey's death and imprisoned by rigid boundaries.

Obviously, the otherness of the other constitutes an absence which is hard to acknowledge. In this respect, Mr. Tuttle can be approached as a representation of Laplanchean enigmatic other that embodies the enigmatic messages of both an internal and an external other. As Michael Naas also suggests: "Mr. Tuttle is a kind of cipher between the living and the dead, the present and the past, what is inside and out" (101). This enigmatic other in the form of Mr. Tuttle represents the internal "'psychical other' or the 'other thing"' in the subject, the unconscious of Lauren, which is also an enigma to the self. The other resides in the subject's experience, but it evades representation and the ego is formed around it. Laplanche defines the unconscious as follows: "Far from being my kernel, [the unconscious] is the other implanted in me, the metabolised product of the other in me: forever an 'internal foreign body'" (Otherness 260). This internal foreign body first shows itself to Lauren, when she recognizes the elements of her own voice in Mr. Tuttle and starts to observe herself being spoken by a stranger. Di Prete defines Lauren's experience as follows: "Put repeatedly in a position of witnessing herself from without, Lauren faces her internal divisions, struggling to confront the insistently ungraspable fact that Mr. Tuttle/Rey is a psychic formation within her own unconscious - is, indeed, herself speaking what she cannot know" (488). Besides, as is emphasized before, Mr. Tuttle represents also the external dead other, Rey, Lauren is attached to. In the course of the novel, Lauren sees to her surprise that Mr. Tuttle not only does imitate her voice but her husband's voice as well. The embodiment of the dead other through Mr. Tuttle shows

how traumatic memories that occupy the psyche without being absorbed or assimilated compulsively return. Mr. Tuttle's presence is marked not only by the mysterious materialization of his body, however, but also by his continuously returning voice. Simulated, repeated, recorded, doubled, Mr. Tuttle's voice insistently addresses Lauren in her struggle for survival. (Di Prete 485) 
Thus, the other both in internal and external terms, is like an enigma persistently speaking to the subject as is perceived in Lauren's relationship to Mr. Tuttle. Subjectivity and the unconscious emerge due to this otherness. As Hinton states, "For Laplanche, enigmatic experiences lie at the core of the subject" (642).

If the analogy between weaving and mourning is taken into consideration, while Lauren is talking to Mr. Tuttle and attempting to replay her memories with Rey, she is weaving her ties to her lost other. When she simultaneously unweaves these ties, that is, analyses her experience with this stranger, she has already started to design a new show as a body artist through her work of mourning. Lauren's body is her shroud of mourning. Like Penelope weaves, unweaves and reweaves her fabric on the loom day and night, Lauren, in a similar repetitive cycle, works on her body and voice.

[T] he poses she assumed and held for prolonged periods, the gyrate exaggerations, the snake shapes and flower bends, the prayerful spans of systematic breathing, life lived irreducibly as sheer respiration. She did [...] her slow-motion repetitions of everyday gestures, checking time on your wrist or turning to hail a cab, actions quoted by rote in another conceptual frame, many times over and now slower and over [...] and your eyes shut tight against the intensity of passing awareness. (TBA 60)

During her work of mourning, Lauren actually learns how to become the other. Towards the end of the novel, it is revealed that Lauren's conversations with Mr. Tuttle is surrounded by the fragments of the tape-recordings of Rey's voice. She is replaying these recordings continually in order to be with Rey and eventually she starts to imitate his voice. Actually, these tape-recordings compose a part of Rey's project of writing his own autobiography. Due to her traumatic loss, Lauren erases herself and becomes a blank space which Rey and the other bodies that surround her during her mourning process insert themselves into. For instance, she imitates a Japanese woman she sees in the street, the landlord who comes to take a piece of furniture from the house, and the answering machine she hears when she calls her friend, Mariella. She develops plural subjectivities and imitations of the gestures of other people, particularly Rey, through her talent of acting. Her body and her voice can alter and represent the exact bodies and voices of the others while she is performing. The novel discloses this aspect through Lauren's close friend Mariella's review on the show which includes her interview with Lauren as well. Mariella writes:

Hartke is a body artist who tries to shake of the body - hers anyway. [...] I have no idea how Hartke alters her body and voice. [...] The last of her bodies, the naked man, is stripped of recognizable language and culture. He moves in a curious manner, as if in a dark room. [...] He wants to tell us something. His voice is audible, intermittently, on tape, and Hartke lip-syncs the words. [...] Then she does something that makes me freeze in my seat. She switches to another voice. It is his voice, the naked man's [...] Not taped, but live. Not lip-sync'd but real 
[...] I search my friend's face but don't quite see her. I'm not sure what she is doing. I can almost believe she is equipped with male genitals. (TBA 110-11, 113-15)

As is observed, the transformation of Lauren's body on stage shows how she moves from one material body into another one by merging herself with other voices by ventriloquizing. Throughout the novel, her conversations with Mr. Tuttle, her bathing him, her feeding him, and her sleeping by him attain a meaningful context when it is announced in this review that all these experiences belong to a performative piece of art. "By erasing all the distinguishing characteristics of her own body, Lauren [...] allows herself to conform to these other identities, no longer imply imitating them but becoming different through these alien presences within her" (Naas 103). Mr. Tuttle, who represents Lauren's external and internal other in her mourning process, is simultaneously a product of her artistic creation. Her body art becomes a representation of her trauma which indicates that she has cured herself of it because trauma, when it is experienced, has no representation. However, the novel does not end with Lauren's performance on the stage. After presenting Lauren surrendering to the healing power of creative art, DeLillo surprises his readers on the very last page when he reveals Lauren's double-sided trauma. It is on this very last page it is learned that she has also solved her initial trauma that has been implanted in her since her childhood through her body art. Lauren's focalization reveals her initial loss: "Her mother died when she was nine. It wasn't her fault. It had nothing to do with her" (TBA 132). This significant final information the reader receives unveils Lauren's vulnerability. When Lauren's initial loss is analysed within Laplanche's understanding of trauma with a particular focus on "afterwardsness," the traumatic function of her feeling responsible for her mother's death and its role in disrupting Lauren's subjectivity can be understood.

According to Laplanche, an unbearable event disrupts subjectivity and positions the subject in the double temporality of trauma. A traumatic initial event, which is not understood as traumatic by the subject at the time it happens, forces itself into the subject's psychic life by the experience of a second event through repetitive actions and dreams after a period of time. Since the initial event is not consciously registered by the subject due to their lack of necessary cognitive tools to grasp the traumatic nature of the event, this event is not processed at the unconscious level of the subject by being repressed either. It is "the implantation of something coming from outside" (Caruth n.p.) which forms an otherness in the subject as is discussed earlier. Thus, the initial event implants the message of the other into the subject. This message remains enigmatic because the subject does not have the cognitive ability to recognize it at the time it occurs. It is the subject's refabricated memory of it that acquires a meaning afterwards and repressed when the primary event is triggered by a second event. Thus, the enigmatic messages coming from not only the external other but also the internal unconsciousother construct a decentred subject "dependent upon the otherness that one always already is" (Hinton 640). This is the reason why, in Laplanche's opinion, 
"the trauma is never locatable in either scene alone but in 'the play of deceit producing a kind of a seesaw effect between two events'" (Caruth n.p.). This process is called "nachträglichkeit" by Freud and "après-coup" by Lacan, which is translated into English as "afterwardsness" by Laplanche. "Afterwardsness" emerges in relation to double temporality and the enigmatic message of the other.

In the light of this discussion of trauma, it can be claimed that the death of Lauren's mother, the initial traumatic event, is cut off from Lauren's memory due to her experiencing of it at an early age and therefore inhabits a realm distanced from her experience. The experience of her mother's death is not repressed by Lauren because it is too shocking to be registered in a meaningful way by a child who is nine years old. Repression can take place only when the experience attains a meaning for the subject to confront. That is, the early loss of the mother cannot be understood as meaningful but might be only registered by Lauren in a partial way. However, this traumatic event, which had not been available to experience, surfaces in the second traumatic loss, Lauren's husband's death. It must have been imposed itself on Lauren's psyche through Rey's death and reminded Lauren of her partially forgotten trauma.

It is mostly thought that the uncovering of the earlier traumatic event is essential to understand the nature of trauma. That is, if Lauren talks about her mother's death and relates what happened to her mother in her early childhood, then the nature of her trauma would be discovered. However, as Di Prete states, "The silence around the death of her mother seems to frame the other, more central silence around the death of her husband" (489). Lauren, as it turns out, is experiencing the symptoms of the traumatic loss of her mother along with the traumatic loss of her husband because she has severely been reminded of her initial loss of mother other when she loses her husband. However, as is observed in the above quotation, it is not her mother's death which is repressed but her belief in her being guilty for, her memory of having fault in her mother's death which is repressed. In other words, her refabrication of her memory about her mother's death following her loss functions as a potential cause for trauma. After her performance on stage, after being healed, she can see things clearly and she recognizes that she was not responsible for her mother's death. The possibility of an initial traumatic event implied in the ending of the novel may generate the following questions: Does Lauren hold herself responsible also for Rey's suicide? Does she think she feels guilty because she could not see it coming like Isabel did and prevent it from happening? She remembers how Rey "had told her that she was helping him recover his soul" (TBA 65). Now he is dead she confronts her failure in helping him to heal his soul. Then, does she think she could have saved him or could have healed him? Did her mother also commit suicide? Is this the reason why her repressed memory of having fault in her mother's death has emerged along with the trauma of Rey's suicide? The answers to these questions are not available to the reader. They remain enigmatic to the readers as well as to Lauren. What is observed at the end of The Body Artist is that "afterwardsness" is no longer affecting Lauren. She is cured of her trauma by fully representing 
it. During her conversations with Mr. Tuttle, Lauren was in a state of "afterwardsness" in which the past and the future merge, not only at the linguistic level in the conversations but also at the experience of temporal order. At the end of the novel, Lauren finds neither Rey nor Mr. Tuttle in the house and she understands that she has to feel "the flow of time in her body, to tell her who she was" (TBA 131).

In conclusion, Lauren's returning to the temporal order is an indication of the end of her mourning and her rebuilt decentred subjectivity on the enigmatic messages of all others which are represented through performative art. In order to survive this unbearable loss, she has to build her boundaries that have dissolved. And since subjectivity can be formed around the enigmatic other, the unconscious, she has to go through the process of being the other. "Mourning provides the opportunity (a demand) to reorganize a new vision of oneself that can encompass both the loss of the loved person and one's memory of that person. But before a new tapestry-the new vision-can be woven, an unweaving must take place" (Browning 789). And this is what Lauren's work of mourning and her performative art have presented to the reader. "Bereavement forces [her] through the agony of thinking, to unravel the fabric of [her] existence, a fabric woven on the loom of the lost other" (Browning 789; Laplanche, Foundations 215). Due to her painful grief, Lauren "unravel[s] the fabric of [her] existence" (Laplanche, Otherness 255) as Penelope did. This is how Lauren's work of mourning unweaves the binds of her utmost traumatic loss - her mother's death at the age of nine - to weave her ties anew to her dead loved ones by means of her body art.

\section{Works Cited}

Brinkema, Eugenie. The Forms of the Affects. Duke UP, 2014.

Browning, Deborah L. "Laplanche on Après-Coup: Translation, Time, and Trauma." Journal of the American Psychoanalytic Association, vol. 66, no. 4, Published online September 24, 2018, Issue published: August 1, 2018, pp. 779-794.

Caruth, Cathy. "An Interview with Jean Laplanche." Postmodern Culture, vol. 11 no. 2, 2001. Project MUSE, doi:10.1353/pmc.2001.0002.

DeLillo, Don. The Body Artist. Picador, 2001.

Di Prete, Laura. "Don DeLillo's The Body Artist: Performing the Body, Narrating Trauma." Contemporary Literature, vol. 46, no. 3, 2005, pp. 483-510.

Freud, Sigmund. "On Transience." The Standard Edition of the Complete Psychological Works of Sigmund Freud, Volume XIV (1914-1916): On the History of the PsychoAnalytic Movement, Papers on Metapsychology and Other Works, pp. 303-307.

---. "Mourning and Melancholia." The Standard Edition of the Complete Psychological Works of Sigmund Freud, Volume XIV (1914-1916): On the History of the PsychoAnalytic Movement, Papers on Metapsychology and Other Works, pp. 237-258.

Hinton, Ladson. "The Enigmatic Signifier and the Decentred Subject." Journal of Analytical Psychology, vol. 54, no. 5, 2009, pp. 637-657.

Kontoulis, Cleopatra and Eliza Kitis. “Don DeLillo's The Body Artist: Time, Language and Grief." Janus Head:Journal of Interdisciplinary Studies in Literature, 
174 | Selen Aktari-Sevgi

Continental Philosophy, Phenomenological Psychology, and the Arts, vol. 12, no. 1, 2011, pp. 222-242.

Laplanche, Jean. Essays on Otherness. Routledge, 1999.

---. New Foundations for Psychoanalysis. Translated by Jonathan House, Unconscious in Translation LLC, 2017.

Naas, Michael. "House Organs: The Strange Case of the Body Artist and Mr. Tuttle." Oxford Literary Review, Vol. 30, No. 1, 2008, pp. 87-108. 